\title{
COLD, HARD JUSTICE LESSONS FROM THE FLEET: INNOVATING FROM THE BOTTOM UP
}

\section{Omar Ha-Redeye*}

With law school graduates encountering increased difficulty in securing articling positions, legal incubators are an alternative way of providing practical training and mentorship opportunities for young practitioners. Not only do they have the potential to help launch careers in law, but they can also play a major role in increasing access to justice. Though legal incubators have been gaining popularity in law schools across the United States, they are still a novel concept in Canada. This article discusses the resources and practice models used by Fleet Street Law, a law practice in Toronto that evolved into the first legal incubator in Canada. The use of innovative business models allowed for greater service of low income and marginalized populations, especially on a "low-bono" rate, and also assisted in providing essential supports for racialized and minority lawyers early in their career. The flexible and innovative nature of a legal incubator was beneficial for the purposes of experimentation, but there were challenges associated with cost and long-term participation. The model of a practitioner-based incubator, as an alternative to traditional-type clinics, should be strongly considered by law schools to help address some of the market needs in the legal community today.

Dans un contexte dans lequel les diplômés des écoles de droit ont de plus en plus de mal à se trouver une place de stage, les incubateurs juridiques constituent une solution de rechange offrant des possibilités de formation pratique et de mentorat aux jeunes professionnels. En plus d'amorcer leur carrière en droit, ceux-ci peuvent jouer un rôle de premier plan pour accroître l'accès à la justice. Bien que les incubateurs juridiques soient de plus en plus populaires dans les écoles de droit des États-Unis, le concept est encore nouveau au Canada. Cet article traite des ressources et des modèles de pratique qu'utilise le cabinet Fleet Street Law, cabinet d'avocats de Toronto qui a évolué au sein du premier incubateur juridique au Canada. Grâce à des modèles d'entreprise innovateurs, il est désormais possible d'offrir davantage de services aux personnes peu fortunées et marginalisées, et ce, à un taux d'aide juridique peu élevé, ainsi que du soutien essentiel aux avocats racialisés et aux avocats des collectivités minoritaires au début de leur carrière. Si la nature souple et innovatrice de l'incubateur juridique s'est révélée avantageuse sur le plan de l'expérimentation, des défis liés aux coûts et à la participation à long terme doivent être relevés. Les écoles de droit devraient envisager sérieusement la possibilité de se tourner vers le modèle de l'incubateur juridique comme solution de rechange aux cliniques traditionnelles afin de répondre à quelques-uns des besoins du marché dans le milieu juridique actuel.

Omar Ha-Redeye, AAS, BHA (Hons.), PGCert, JD, LLM, CNMT, RT(N)(ARRT), is a lawyer and legal innovator based in Toronto. His contributions towards improving the legal system and innovation in law have been recognized through the Queen Elizabeth II Diamond Jubilee Award and the Ontario Bar Association Foundation Award. He is an Adjunct Faculty member at Ryerson University, where he teaches in the Ted Rogers School of Business. 


\section{INTRODUCTION}

Over the past seven years, several of Canada's largest law firms have merged or joined with other international firms. In 2010, Ogilvy Renault LLP joined Norton Rose LLP, added Macleod Dixon LLP in 2012, and became Norton Rose Fulbright in 2013. Fasken Martineau DuMoulin joined a South African firm in 2012, and then a three-way merger resulted in the creation of Dentons in 2013. Davis LLP joined DLA Piper in 2015, and, in 2016, Gowling Lafleur Henderson LLP announced its intention to join with United Kingdom-based Wragge Lawrence Graham \& Co LLP. The contraction of the big law firms has contributed to a shortage of articling positions, creating challenges for licensees who need practical training and mentorship opportunities. In 2013, 15 percent of law graduates could not find articling positions. ${ }^{1}$ The articling shortage has been compounded by other factors, such as increased class sizes in law schools and a surge in Ontario residents studying law abroad and then seeking articling positions at home.

Out of this tempest of challenges has emerged a drive among young practitioners to innovate and find new ways to practise law. Our project, Fleet Street Law, was developed in 2011 from the collaboration of five sole practitioners who, soon after getting called to the bar, set up an independent practice. The project changed and developed over time, with most of these founding members moving on to other careers, practices, or delivery models. The lessons learned and the collected resources were identified as being valuable to other young lawyers, so it shifted towards becoming a "legal incubator," the first of its kind in Canada. To date, Fleet Street Law has had over thirty-five lawyers go through our system, with over fifty students receiving additional training through their participation. In turn, these practitioners were able to increase access to justice by developing more affordable models of practice, providing legal services for low- to moderate-income individuals who would otherwise not be able to access them. The purpose of this article is to discuss how an incubator model can assist early career practitioners, especially in meeting access to justice issues, and how such a model can be extended in a sustainable fashion, likely with support from educational institutions. The article proposes that an incubator model may be effective in meeting some of the access-to-justice needs in society today, and in supporting young practitioners in meeting those needs.

In the second part of the article, we illustrate how a legal incubator model may play a role in assisting young practitioners, particularly in developing mentorship and supports for historically marginalized licensees. The third part discusses the creation of Fleet Street Law, from its inception as a legal practice through its transition into a legal incubator. The fourth part reviews the specific resources that were used to support Fleet Street Law and the innovations that developed over the course of the project. Finally, the fifth part looks at limitations and next steps of the legal incubator and the possibility of adopting parts of this model for Canadian law schools.

\section{MENTORSHIP, PRACTICE SUPPORT, AND INCUBATORS}

\section{A. The General Importance of Mentorship in Law}

In Ontario, the practice of law began as an apprenticeship model, based on a close working relationship with an established lawyer in the jurisdiction. The apprentice would provide work for this supervising lawyer, who in turn would mentor the apprentice and provide the opportunities to learn legal skills.

Julia Johnson, “Ontario's Articling Shortage Widens to 15\% as LSUC Considers Alternatives," Financial Post (8 May 2012), online: $<$ http://business.financialpost.com/legal-post/ontarios-articling-shortage-widens-to-15-as-lsuc-considersalternatives $>$. 
Remnants of this model can still be found in the modern articling system, but critics of the current system have pointed out that the close working relationship and emphasis on skill development have all but faded in the current articling process. To help provide some peer supports, legal organizations in Ontario have launched their own mentorship programs, including the Ontario Bar Association [OBA] and the Advocates Society. In 2014, the Law Society of Upper Canada [LSUC] introduced the pilot Law Practice Program [LPP]. Composed of a four-month training course and a four-month work placement, licensees can opt to complete the LPP instead of articling. ${ }^{2}$ The training course is done independently, replicating "the experience of working in a law firm using interactive web-based modules and digital simulation tools," differing from the traditional pedagogical method of imparting legal knowledge. ${ }^{3}$ The work placement provides licensees with the opportunity to work in close proximity with lawyers in a practice setting. However, the relatively short duration of four months does not necessarily foster a close relationship between the participants.

The shortcomings of the LPP, combined with criticisms of the current articling system, have created greater awareness of the increased need for mentorship in the profession. ${ }^{4}$ A growing concern around mentorship is that historically marginalized populations in the legal profession, such as women and racialized minorities, fail to have the proper social networks within the established legal community to gain the support they need to thrive in practice. ${ }^{5}$ Specifically, racialized lawyers in Ontario believe they face discriminatory behaviour and assumptions as part of their everyday professional experiences, and they have expressed feelings of alienation, lack of support and professional networks, and the inability to obtain the mentoring that is needed to succeed. ${ }^{6}$ For this reason, many of the advocacy groups within the profession have also developed their own mentorship programs, including the Women's Law Association of Ontario [WLAO], the Canadian Association of Black Lawyers [CABL], and the Federation of Asian Canadian Lawyers [FACL]. Recent reports by the Equity and Aboriginal Issues Committee of the LSUC have revealed that 40 percent of racialized licensees in Ontario believe that ethnic and racial identity is a barrier to entry to practice. ${ }^{7}$

Mentorship helps women build attachment and commitment to the legal profession, along with career success overall and job satisfaction, and multiple mentors can provide access to a variety of different

2 Law Society of Upper Canada (LSUC), "Pathways Pilot Project" (9 November 2016), online: <www.lsuc.on.ca/Pathways/>.

3 LSUC, "Law Practice Program" (October 2016), online: <www.lsuc.on.ca/licensingprocess.aspx?id=2147497057>.

4 The Law Practice Program (LPP) has also played an important role in highlighting the barriers faced by racialized licensees in the profession. Approximately a third of LPP candidates identify as racialized, as compared to 21 percent of articling students. Alex Robinson, "LSUC Committee Recommends Scrapping LPP," Law Times (19 September 2016), online: <www.lawtimesnews.com/author/alex-robinson/lsuc-committee-recommends-scrapping-lpp-12874/>; Michelle Flaherty \& Alain Roussy, “The Law Practice Program: Tackling Racial Inequality in the Legal Profession?” Ottawa Faculty of Law Working Paper no 2015-39, online: <https://papers.ssrn.com/sol3/papers.cfm?abstract_id=2704440>.

5 Fiona M Kay et al, "Principles in Practice: The Importance of Mentorship in the Early Stages of Career Development" (2008) 31:1 Law and Policy 69.

6 Julius Melnitzer, "Non-White Lawyers Feel Alienated, Report Finds," Law Times (3 November 2014), online: $<$ www.lawtimesnews.com/201411034294/headline-news/non-white-lawyers-feel-alienated-report-finds>.

7 Equity and Aboriginal Issues Committee, "Report to Convocation" (22 September 2016), online: $<$ www.lsuc.on.ca/uploadedFiles/For_the_Public/About_the_Law_Society/Convocation_Decisions/2016/ConvocationSeptember-2016-Equity-and-Aboriginal-Issues-Committee.p.pdf $>$; Equity and Aboriginal Issues Committee, "Strategies to Address Issues of Systemic Racism in the Legal Profession" (2 December 2016), online: <www.lsuc.on.ca/uploadedFiles/Equity_and_Diversity/Members/Challenges_for_Racialized_Licensees/Working-Together-for-ChangeStrategies-to-Address-Issues-of-Systemic-Racism-in-the-Legal-Professions-Final-Report.pdf $>$. The consultation report states, "racialization is a constant and persistent factor affecting licensees during entry into practice and opportunities for career advancement." 
learning resources and networking channels. ${ }^{8}$ Research has indicated that women who lack access to mentors were less likely to advance in their careers and more likely to leave their practice. ${ }^{9}$ Given that law is traditionally a male-dominated profession, lack of mentorship opportunities inevitably contributes to the cycle of fewer women rising to senior positions and fewer mentorship opportunities for junior practitioners. ${ }^{10}$ The importance of mentorship for racialized minorities was highlighted in the LSUC disciplinary proceedings in Law Society of Upper Canada v Selwyn Milan McSween. ${ }^{11}$ The basis of the discipline included conduct issues around real estate transactions, and the lawyer referenced his impoverished background in Jamaica. He told the panel: "As much as I regret my own responsibility in this, I regret some of the circumstances didn't really favour me in terms of getting help from others. I went to other lawyers, senior lawyers. I asked them for help. I wasn't able to get help." 12 Although the Law Society Appeal Panel upheld the discipline, they modified it in part with the dissent by Clayton Ruby and Constance Backhouse. ${ }^{13}$

The dissent in McSween referred to a number of cases, reports, and articles to highlight systemic racism and discrimination against members of the black community in Canada. It also stated that the hearing panel erred by failing to provide sufficient weight to any systematic disadvantages that the licensee had faced in his practice in Ontario:

[72] The research into Canadian legal history shows that systemic racism has had a substantial impact on the legal profession. It demonstrates that ideas of legal "professionalism" have been used to exercise power and exclusion based on gender, class, religion, and race. The first minority individuals who sought admission to the legal profession faced significant barriers. Those who succeeded in obtaining entry found that those barriers continued to impact upon their careers when they attempted to practise. Significantly, an increased risk of disbarment was one such barrier for racialized lawyers. [73] It would be misguided to be aware of this history and yet ignore its contemporary incarnations simply because the legal profession has today become much more diverse. The legal profession has made no concerted effort to rid itself of the racism inherent in the practice. As the evidence in this case illustrates, racialized lawyers continue to face barriers not experienced by their colleagues. ${ }^{14}$

These barriers included: fewer job opportunities (including articling positions); fewer opportunities for advancement within firms; and significantly less support from peers, particularly in practice management and resources related to substantive areas of law. The lawyer in McSween was still relatively young in his

8 Kay et al, supra note 5; see also Phyllis Horn Epstein, Women-at-Law: Lessons Learned along the Pathways to Success (Chicago: American Bar Association, 2004).; G Melton Mobley et al, "Mentoring, Job Satisfaction, Gender, and the Legal Profession" (1994) 31 Sex Roles 79. Sheila Riley \& David Wrench, "Mentoring among Women Lawyers" (1985)

15 Journal of Applied Psychology 374.

$9 \quad$ Riley \& Wrench, supra note 8 at 445.

10 Kay et al, supra note 5; see also Elizabeth K McMannus, "Intimidation and the Culture of Avoidance: Gender Issues and Mentoring in Law Firm Practice" (2005) 33 Fordham Urban LJ 217; Nancy J Reichman \& Joyce S Sterling, "Recasting the Brass Ring: Deconstructing and Reconstructing Workplace Opportunities for Women Lawyers" (2002) 29 Capital University L Rev 923.

11 Law Society of Upper Canada v Selwyn Milan McSween, 2010 ONLSHP 33.

12 Ibid at 111 at para 3 .

13 Ibid at 3

14 Ibid. 
profession, despite his older age, and did not have the same supports in place as others in the field. The discipline decision in McSween corresponded with the initial development of the Fleet Street Law project, and the founding members noted the discipline with keen interest. Almost all of the members, and the majority of the subsequent participants, were from historically marginalized populations. The purpose and the intent of the project were to ameliorate some of these disadvantages and mitigate the risk of sole practice as best as possible. The model that eventually emerged was one of a legal incubator.

\section{B. What Are Incubators and Legal Incubators?}

The idea of incubators in the business world is not new. ${ }^{15}$ Historically, incubators were used to revitalize declining manufacturing areas, and they can be traced back to plant closures in New York in the 1950s. ${ }^{16}$ Currently, incubators are used in the technology sector for small business development, specifically for promoting growth through innovation and the application of technology. ${ }^{17}$ These incubators give promising new companies and firms the advantages they need to grow into successful members of a competitive market. While each incubator uses their own methods, generally they provide access to starting funds, networking opportunities and resources, as well as hands-on mentorship. In Canada, the federal government recognizes the importance of incubators for the economy, providing funding to qualifying incubators through the Canada Accelerator and Incubator Program to encourage new businesses and entrepreneurs. ${ }^{18}$

Some members of the bar have expressed apprehension about changes in the legal marketplace and have mobilized to change and respond. The Canadian Bar Association's [CBA] Legal Futures Initiative conducted extensive research and consultations over two years and released a report on the changing legal marketplace and specifically referred to incubators as one strategy to promote innovation in the legal profession. ${ }^{19}$ The report describes the purpose of legal incubators as being to "help recent law graduates transition into sustainable practice situations to serve individuals and small businesses, as well as through virtual practice arrangements." ${ }^{, 20}$ The use of incubators is directly tied in the report to another CBA initiative, "Reaching Equal Justice," which focuses on access to justice. ${ }^{21}$ This report draws on the Hague Institute for the Internationalisation of Law [HiiL] to describe an ecosystem necessary to nurture innovation, one that fosters critical thinking outside of regulations. The report also states that experimentation allows for prototypes to fail and then adapt to be successful rather than needing to follow a set of rules. ${ }^{22}$

Recently, a number of different types of legal incubators have emerged in Canada. In 2014, Torys LLP launched a legal incubator in their Halifax office to develop new and efficient ways to deliver their legal

15 Rustam Lalkaka, “Technology Business Incubators to Help Build an Innovation-Based Economy” (2002) 3:2 Journal of Change Management 167.

16 Rudy Aernoudt, "Incubators: Tool for Entrepreneurship?" (2004) 23:2 Small Business Economics 127.

17 Rhonda G Phillips, "Technology Business Incubators: How Effective as Technology Transfer Mechanisms?” (2002) 24:3 Technology in Society 299.

18 National Research Council Canada, "Canada Accelerator and Incubator Program” (2015), online: <www.nrccnrc.gc.ca/eng/irap/caip/>.

19 Canadian Bar Association (CBA), "Futures: Transforming the Delivery of Legal Services in Canada" (2014), online: $<$ www.cba.org/CBAMediaLibrary/cba_na/PDFs/CBA\%20Legal\%20Futures\%20PDFS/Futures-Final-eng.pdf $>$.

20 Ibid at 35.

21 CBA, "Reaching Equal Justice: An Invitation to Envision and Act" (2013), online: $<$ www.cba.org/CBAMediaLibrary/cba_na/images/Equal\%20Justice\%20-\%20Microsite/PDFs/EqualJusticeFinalReporteng.pdf $>$.

22 Ibid at 139. 
work. ${ }^{23}$ Ryerson University launched its Legal Innovation Zone [LIZ] in 2015 to provide a co-working space for people and ideas to change the legal system. ${ }^{24}$ In early 2016, LIZ partnered with Osler Hoskin \& Harcourt LLP to provide the start-ups with some of the resources of a large law firm. ${ }^{25}$ Soon after, the MaRS Discovery District launched a LegalX cluster to promote innovation in law. ${ }^{26}$ However, none of these are the types of incubators discussed in this article. Torys may be innovating legal ideas or processes, but these are all internal to their firm. Similarly, LIZ and LegalX are incubating small businesses that provide services to law firms or the general public. Although the focus is on innovation and improving processes, they are not incubating lawyers and the practice of law.

Legal incubators that focus on practice are essentially organizations that allow law students or recent graduates to "learn by doing." Students, lawyers, and paralegals join the legal incubator to access the support and job experience needed to get started in the industry. In essence, it is a training program for setting up a practice, providing assistance in the areas of running a business, mentorship, skill development, and building a client base. It also provides the participants of the program with a workspace and the necessary resources (that is, fax, computer, telephone, office supplies) required to run a successful practice. A more experienced senior lawyer is usually available onsite to oversee the group of incubator participants and to assume the role of mentor. ${ }^{27}$ In Canada, legal incubators of all types are still a novel idea. The approach adopted by Fleet Street Law is to support practitioners through associations and peer mentoring, in addition to some material and strategic supports. This creates opportunities for participants and students to gain real world experience while maintaining an emphasis on access to justice. ${ }^{28}$

\section{Why We Need Legal Incubators for Mentorship}

Neil Hamilton and Lisa Montpetit Brabbit define mentoring as "the process by which mentor and protégé work together to identify and help the protégé work towards professional goals." ${ }^{29}$ They suggest that mentorship serves four primary functions in the development and growth of both the law student and the new practitioner. First, through coaching and project assignment, the mentor builds up the knowledge and understanding of how to operate a "real world" practice. ${ }^{30}$ Second, mentorship provides an opportunity for building up the protégé's sense of self-esteem and confidence in their work. Third, the mentor plays the role of paragon, with the protégé learning by watching them work and picking up their good habits. ${ }^{31}$ Lastly, the mentor plays a fundamental role in building up a sense of professionalism in the protégé's work and instilling the core principles and values essential for good practice. ${ }^{32}$ Legal incubators

23 Jeff Gray, "Bay Street Law Firm Launches Legal 'Incubator' in Halifax,” Globe and Mail (2 July 2014), online: <www.theglobeandmail.com/report-on-business/industry-news/the-law-page/bay-street-law-firm-launches-legalincubator-in-halifax/article19405816>.

24 Legal Innovation Zone, “About," online: <www.legalinnovationzone.ca/about/>.

25 Jennifer Brown, “Osler Partners with Ryerson's Legal Innovation Zone,” Canadian Lawyer Magazine (26 January 2016), online: <www.canadianlawyermag.com/legalfeeds/3096/osler-partners-with-ryerson-s-legal-innovationzone.html>.

26 MaRS, "MaRS Launches LegalX to Build Legal Entrepreneurship and Advance the Future of Law" (22 June 2015), online: <www.marsdd.com/media-centre/mars-launches-legalx-to-build-legal-entrepreneurship-and-advance-the-futureof-law/>.

27 Randy Trick, "Legal Incubators Helping Hatch Solo Practices” (2013) 67:18 NWLawyer 18.

28 Fleet Street Law, “About Legal Incubators" (2016), online: <www.fleetstreetlaw.com/about-fleet-street-law/>.

29 Neil Hamilton \& Lisa Montpetit Brabbit, "Fostering Professionalism through Mentoring" (2007) 57:1 Journal for Legal Education 5.

$30 \quad$ Ibid at 6.

$31 \quad$ Ibid at 7.

32 Ibid at 17. 
act as venues for encouraging like-minded individuals to form a collective community, who then share advice, mentorship, and resources. ${ }^{33}$

In Canada, job dissatisfaction among young lawyers working in traditional law firms is prompting a shift towards alternatives. Allison Speigel cites the billable hour model and clients' refusal to pay for training as contributing factors. ${ }^{34}$ Instead of attending court or going to meetings, they end up doing more of the grunt work such as reviewing documents. ${ }^{35}$ The benefit provided by legal incubators is that young practitioners can gain hands-on skills-based experiences outside the traditional billing model, creating a more enriching and rewarding approach to practice. The potential of this shift is to turn solo practice into a more attractive option for young lawyers rather than an option of last resort. The increased control, greater flexibility, and opportunity for work-life balance are all values that resonate more strongly with those looking for fulfilment in their careers. ${ }^{36}$

The need for practitioners to obtain supports in developing a practice was identified by Fred Rooney, director of the International Justice Center for Post-Graduate Development at the Touro Law Center. He commented on these issues, stating: "The unfortunate reality was, and still is, that compassionate and talented lawyers - even those with a deep commitment to working in underserved communities - need to learn how to run a practice quickly or be forced to close up shop., ${ }^{37}$ As a result, Rooney created the Community Legal Resource Network [CLRN] in 1998 to help fund and train young legal practitioners in the New York City area, while encouraging new lawyers to practise in underserved areas. In 2007, the CLRN evolved into the City University of New York [CUNY] Incubator. ${ }^{38}$ The CUNY Incubator appears to have been successful in supporting practice. One student who went through the program commented that they "wouldn't be as knowledgeable in the management of the practice ... you have mentors that are accessible, that guide you by the hand in terms of what you need to do to have a successful practice, to set up a court calendar where you know what cases are on, what deadlines you need to meet." 39

Another aspect of practice that new practitioners face is high levels of work-related stress. This can be described as the new occupational hazard for many professional fields in a service-based economy, but it can be particularly acute in a profession that is entrenched in conflict and dispute. Mark Heekin writes: "Lawyer depression, stress-related physical ailments, alcoholism, drug use, and other self-destructive behaviors ... continue to increase at a steady pace." ${ }^{, 40}$ Depression is the leading cause of suicide, and it is suggested that lawyers have the fourth highest suicide rate across all professions after dentists,

33 Jules Lobel \& Mathew Chapman, "Bridging the Gap between Unmet Legal Needs and an Oversupply of Lawyers: Creating Neighbourhood Law Offices - the Philadelphia Experiment" (2015) 22:1 Virginia J Social Policy \& the Law 72.

34 Allison Speigel, "Why So Many Young Lawyers Dislike Their Jobs," Globe and Mail (8 June 2016), online: $<$ www.theglobeandmail.com/report-on-business/small-business/sb-money/why-so-many-young-lawyers-dislike-theirjobs/article29807625/>.

35 Ibid.

36 PwC, "PwC's NextGen: A Global Generational Study" (2013), online: <www.pwc.com/gx/en/hr-managementservices/pdf/pwc-nextgen-study-2013.pdf > . See also Donna L Haegera \& Tony Linghamb, "A Trend toward Work-Life Fusion: A Multi-Generational Shift in Technology Use at Work" (2014) 89 Technological Forecasting and Social Change 316; Dan Schawbel, "The Beginning of the End of the 9-to-5 Workday?” Time Magazine (21 December 2011), online: $<$ http://business.time.com/2011/12/21/the-beginning-of-the-end-of-the-9-to-5-workday/>.

37 Fred Rooney \& Justin Steel, "Exporting the Legal Incubator: A conversation with Fred Rooney," Legal Studies Research Paper Series no 15-05 (2014) at 111.

38 Ibid at 111.

39 Ed Finkel, "INCubator-Style Programs Growing Among Law Schools" (2013-2014) 42:2 Student Lawyer Magazine 29.

40 Mark Heekin, "Resilience Training in Law Incubators" (2016) 1:2 Journal of Experiential Learning 9. 
pharmacists, and physicians. ${ }^{41}$ In recent years, there has been a growing number of mental health initiatives to raise awareness, start conversations, and foster mental wellness within the legal profession. The role of mentorship through incubators can help mitigate the impact of vocational based stressors of this type.

Incubators can potentially foster greater "psychological resilience," defined as the ability for a person to withstand and balance the mental effects of stressful situations. ${ }^{42}$ One method used to promote psychological resilience is a "round-robin" discussion for members of the incubator to discuss aspects of the business with each other, providing emotional support to deal with the stresses of the job. This emotional support is a gap that incubators can fill for new lawyers as they transition from students to professionals. Psychologically resilient practitioners are generally more optimistic and can better handle criticism or failures, leading to "greater personal and professional satisfaction." ${ }^{43}$ By building up and nurturing the emotional needs of new practitioners, clients ultimately benefit by receiving more competent and capable services.

\section{Legal Incubators around the World}

In the United States, the earliest legal incubators were formed in the late 1890s and early 1900s as "legal dispensaries," where law students practised their skills by offering legal services to the poor. ${ }^{44}$ These early legal clinics spread to a few law schools but did not gain prominence until the 1960s and the rise of the civil rights movement. ${ }^{45}$ By the end of the twentieth century, law school legal clinics started offering specialized legal services, such as small business development, through community partnerships. In 1998, the Institute for Justice [IJ], a law firm from Washington, DC, partnered with law students from the University of Chicago to create the IJ Clinic on Entrepreneurship [IJ Clinic]. ${ }^{46}$ Serving poor neighbourhoods in Chicago, it was founded on the premise that entrepreneurship is "the most powerful opportunity for self-sufficiency, self-determination, and economic improvement," while recognizing that government bureaucracy is a major barrier for those wanting to start a business. ${ }^{47}$ The IJ Clinic's three goals were to provide quality legal representation on transactional matters, to train law students to be advocates for entrepreneurs, and to help entrepreneurs navigate the regulatory process. ${ }^{48}$ To accomplish this, the IJ Clinic developed tools such as "an Alphabet Soup of Laws," a six-page document that listed the names of relevant federal, state, and municipal laws. In their first three years of operation, the IJ Clinic assisted more than 100 new entrepreneurs. ${ }^{49}$

In recent years, legal incubators have been gaining popularity across the United States as a response to the adverse impact of the Great Recession of 2008 on the legal job market. ${ }^{50}$ Legal incubators provide a

41 Orlando Da Silva, "Speaking for Mental Health Awareness and Support" (Mental Health Week Event, Osgoode Hall, Law Society of Upper Canada, Toronto, 3 May 2016) [unpublished].

42 Heekin, supra note 40 at 304-305.

43 Ibid at 296.

44 Margaret Martin Barry et al, "Clinical Education for This Millennium: The Third Wave" (2000) 7 Clinical L Rev 1.

45 Ibid at 13.

46 William H Mellor \& Patricia H Lee, "Institute for Justice Clinic on Entrepreneurship: A Real World Model in Stimulating Private Enterprise in the Inner City" (2001) 5 J Small \& Emerging Business L 72.

47 Ibid.

48 Ibid at 73 .

49 Ibid at 80.

50 John Christian Waites \& Fred Rooney, "What We Know and Need to Know about Law School Incubators" (2015) 67:503 South Carolina L Rev 519; Lorne Sossin, "Experience the Future of Legal Education" (2014) 51:4 Alberta L Rev 850. 
viable solution to the concerns faced by many young lawyers who lack opportunity and experience in the legal profession, while addressing the lack of access to justice among low- to moderate-income individuals. ${ }^{51}$ The legal incubator is modelled after the traditional business incubator that assists entrepreneurs with start-up business support, not only in terms of logistics and overhead but also with mentorship and opportunities to network with providers of business capital. ${ }^{52}$ CUNY has had the CUNY School of Law Launch Pad for Success and various other legal incubator programs since 2009. ${ }^{53}$ It employs recent graduates of their own law program from the time they write the bar exam to when they receive the results, usually between the months of July and November. During this period, students have the opportunity to work on pro bono cases in vital areas such as landlord and tenant disputes or uncontested divorces. Students gain meaningful experience in legal practice while working in the public interest by improving access to justice. ${ }^{54}$

In 2014, the University of Detroit Mercy School of Law formed its own small firm incubator program, which was designed to provide a supportive environment for new graduates who were committed to beginning a solo or small practice focused on serving low and moderate-income individuals. ${ }^{55}$ The program model was an eleven-month commitment to building a practice representing clients of modest incomes on "low-bono or sliding fee scale." Participants received free office space, some supportive services, structured training, and mentoring, with 25 percent of the participant's time being pro bono work, while the remaining 75 percent of the time was spent developing their own law practice. ${ }^{56}$

In the San Francisco Bay area, five law schools banded together in 2016 to create the Bay Area Legal Incubator [BALI] program. The goal of this program is to help students develop a legal practice niche, based on a reduced fee of US $\$ 100$ an hour for their services. BALI will run for two years, providing students with a US $\$ 500$ a month stipend for their first six months to cover their overhead expenses. The stipend ends after six months, and after a year, students will be expected to pay BALI US \$250 a month, with payments increasing to US $\$ 500$ a month for the last six months of the program. Participants therefore receive monetary support during the early business cycle on a commitment to reinvest money into the program once their business grows. Through this method, BALI aims to encourage the entrepreneurial spirit of its students and trains them to provide specialized, yet affordable, legal services to underserved communities. The growth of incubator programs across the United States, despite dropping applications to law schools, suggests that incubators are here to stay. ${ }^{57}$

In the United Kingdom, the Center for Commercial Law Studies at Queen Mary University of London has set up their own legal incubator called qLegal to fill the demand for new intellectual property (IP) lawyers. This incubator operates under the guidance of legal industry professionals as students take on pro bono cases for small businesses in the information technology sector, where IP is particularly important. ${ }^{58}$

51 Lobel \& Chapman, supra note 33 at $72-74$.

52 Ibid.

53 Fern A Fisher, "Launch Pads and Incubators: Providing Access to Justice Using Law Graduates and New Lawyers" (2014) 53:1 Judges' Journal 4.

54 Ibid at 2 .

55 Tammy M Kudialis, "A Proposed Model for Creating a Law School Based Solo or Small Firm Incubator Program" (2015) 83 University of Missouri-Kansas City L Rev 823, online: <www.americanbar.org/content/dam/aba/administrative/delivery_legal_services/ls_del_Kudialis_83_UMKC_823_Summer_2015.authcheckdam.pdf>.

56 Ibid at 6.

57 Amy Phan Taylor, "Incubators: A Program to Launch Solos Is Born” (2015) 44:2 Student Lawyer 16.

58 Adam Palin, "Patent Wars Fuel Growth of Jobs in Intellectual Property Law," Financial Times (10 November 2013), online: <www.ft.com/content/2a51c9ac-3d87-11e3-b754-00144feab7de>. 
Queen Mary University of London is also a member of the iLINC Network, which connects technology start-ups with law students offering legal services from universities across Europe and the Middle East. ${ }^{59}$

\section{E. Using Legal Incubators to Promote Access to Justice}

According to Stephen Wizner, law students "should learn not only the techniques of advocacy, but also the importance of advocacy in helping individuals solve their problems, defend their rights, and achieve their goals. ${ }^{, 60} \mathrm{He}$ suggests that advocating on behalf of low-income clients can help students develop the professional responsibility and motivation to work in the public interest. ${ }^{61}$ Given the emphasis on skills training in law schools, students tend to see their education as preparation for practice rather than participation in the struggle for access to justice. ${ }^{62}$ Wizner also argues that law schools should share some of the obligation of increasing access to justice through their legal clinics, by mainly serving clients from underserved communities. ${ }^{63}$ Clinical education is also one of the best ways to get students to "think like a lawyer" and start developing a sense of professional responsibility. ${ }^{64}$ At Yale Law School, clinical education starts as early as the second semester, and students tackle a variety of legal issues with opportunities for social reform, as evidenced by the Mental Hospital Legal Services Project and the Prison Legal Services Project. ${ }^{65}$ Upper-year students serve as "junior supervisors," sharing responsibility with faculty for the operation of the legal clinic and for the quality of legal assistance offered to clients. ${ }^{66}$ At the University of Georgia, students assist low-income clients through fieldwork in the community, learning to identify people's needs, making connections with services, and uncovering how to best fill the gaps using the law. ${ }^{67}$

One of the ways to address the unmet needs of low- and moderate-income clients is having lawyers work "low bono," where legal services are offered at reduced fees that are usually 40 to 50 percent lower

59 iLINC, "The iLINC Network" (2017), online: <www.ilincnetwork.eu/law-incubators/the-ilinc-network/>.

60 Stephen Wizner, "Beyond Skills Training" (2001) 7 Clinical L Rev 327 at 328.

61 Ibid. See also Stephen Wizner, "Can Law Schools Teach Students to Do Good? Legal Education and the Future of Legal Services for the Poor" (2000) 3 CUNY L Rev 259; Phillip M Genty, "Clients Don’t Take Sabbaticals: The Indispensable in-House Clinic and the Teaching of Empathy Clinical Essay" (2000) 7 Clinical L Rev 273.

62 Ibid at 330. See also Stephen Wizner, "Is Learning to 'Think Like a Lawyer' Enough?” (1998) Faculty Scholarship Series 1846; Stephen Wizner "Repairing the World through Law: A Reflection on Robert Cover's Social Activism" (1996) Faculty Scholarship Series 1848, online: <http://digitalcommons.law.yale.edu/fss_papers/1848/>; Lucie E White, "The Transformative Potential of Clinical Legal Education" (1997) 35:3/4 Osgoode Hall LJ 603, online:

$<$ http://digitalcommons.osgoode.yorku.ca/cgi/viewcontent.cgi?article=1583\&context $=$ ohlj $>$.

63 Stephen Wizner, "Walking the Clinical Tightrope: Between Teaching and Doing" (2004) 4 U Md LJ Race, Religion, Gender \& Class 259.

64 David M Tanovich, "Learning to Act Like a Lawyer: A Model Code of Professional Responsibility for Law Students" (2009) 27 Windsor YB Access to Justice 1, online: <www.lsuc.on.ca/media/eleventh_colloquium_tanovich.pdf $>$. See also Ann Marie Cavazos, "The Journey toward Excellence in Clinical Legal Education: Developing, Utilizing and Evaluating Methodologies for Determining and Assessing the Effectiveness of Student Learning Outcomes" (20102011) 40 Southwestern L Rev 1, online: <http://commons.law.famu.edu/faculty-research/50/>.

65 Stephen Wizner \& Dennis Curtis, "Here’s What We Do: Some Notes about Clinical Legal Education” (1980) 29 Clev St L Rev 673.

66 Ibid at 682 .

67 Wizner, "Beyond Skills Training," supra note 60 at 339. For more information on designing legal clinics and clinical courses, see Philipp G Schrag, "Constructing a Clinic" (1996) 3 Clinical L Rev 175; Roy T Stuckey, "Teaching with Purpose: Defining and Achieving Desired Outcomes in Clinical Law Courses" (2006) 13 Clinical L Rev 807; Roy T Stuckey, "Ensuring Basic Quality in Clinical Courses" (2000) 1 Intl J Clinical Legal Research 47; Alex J Hurder et al, Clinical Anthology: Readings for Live-Client Clinics, 2d ed (New York: LexisNexis, 2011); Margaret M Barry et al, "Teaching Social Justice Lawyering: Systematically Including Community Legal Education in Clinical Legal Education" (2012) 18 Clinical L Rev 401. 
than market rates. ${ }^{68}$ The concept was first introduced in a 1994 report on the Greater Access and Assistant Project of the American Bar Association's Young Lawyers' Division. ${ }^{69}$ It was a national effort to address the need for legal representation for "gap clients" - individuals who could not afford to hire a lawyer but who had incomes that were too high to qualify for government-funded legal assistance. In 1997, the Law School Consortium Project helped US law schools develop the infrastructure to encourage solo practitioners or small firms to deliver low bono legal services to gap clients. Legal incubators have been the result, where law schools sponsor new practitioners, reducing their operating costs while connecting them with clients who can afford low bono fees. ${ }^{70}$

In Canada, the value and potential of legal incubators have yet to be properly considered by law schools and the provincial governments that oversee the court systems. Their use goes beyond law school training programs, as they create viable solutions for the growing concerns related to access to justice. Unrepresented litigants are a common presence in civil courts, where decisions have as big of an impact on their lives as criminal matters, affecting rights to personal safety and dignity on issues such as child protection and landlord-tenant disputes. ${ }^{71}$ Legal representation for low-income individuals has traditionally taken the form of lawyers working pro bono or through government-funded legal aid. Pro bono work has been an established part of the legal profession in Canada, with the CBA recommending that lawyers contribute fifty hours of pro bono work per year. ${ }^{72}$ However, it is not mandatory, and provincial law societies do not require disclosure of the types of activities performed. ${ }^{73}$ It is generally understood that the availability of pro bono representation is mainly based on the supply of lawyers who are willing to volunteer their services. ${ }^{74}$ From an access-to-justice standpoint, pro bono work is most effective as a supplement to, rather than as a replacement for, a properly funded legal aid system. ${ }^{75}$

Legal Aid Ontario [LAO] offers free legal services to low-income individuals, with a priority on criminal law matters as opposed to civil law. ${ }^{76}$ Cuts to LAO in the 1990 s meant that assistance was restricted to civil cases in the areas of family law, immigration, and refugee hearings and to some administrative tribunals such as the Landlord and Tenant Board. ${ }^{77}$ Current eligibility for legal aid is set at

68 Luz E Herrera, "Encouraging the Development of 'Low Bono' Law Practice” (2014) 14:1 U Md LJ Race, Religion, Gender \& Class 2 [Herrera, "Encouraging the Development"].

69 Ibid at 4

70 Ibid at 5.

71 Brian Seaman, "Legal Equality, Poverty, and Access to Justice" (2006) Law Now 1, online: $<$ http://archive.lawnow.org/d/sites/default/files/F5306.pdf $>$. See also Jeremy Hainsworth “"Window of Opportunity” Closing to Fix Country's Access to Justice," Lawyers Weekly (10 May 2013), online:

$<$ http://lawyersweekly.ca/articles/1895>; Ronald TY Moon, "Access to Civil Justice: Is There a Solution?” (2004-2005)

88:4 Judicature 155; Deborah Rhode, "Access to Justice: Connecting Principles to Practice" (2004) 17 Georgetown J Legal Ethics 369.

72 CBA, “"Tension at the Border': Pro Bono and Legal Aid” (Ottawa: CBA, 2012), online: <http://www.cba.org/CBAMediaLibrary/cba_na/images/Equal\%20Justice\%20\%20Microsite/PDFs/ProBonoPaper_Eng.pdf>.

73 Lorne Sossin, "The Public Interest, Professionalism, and Pro Bono Publico" (2008) 46 Osgoode Hall LJ 148 at 149.

74 Ibid.

75 Justin Hansford, "Lippman's Law: Debating the Fifty-Hour Pro Bono Requirement for Bar Admission” (2014) 41 Fordham Urban LJ 1141. See also Sydney Howe-Barksdale, "The Case against Mandatory Pro Bono Programs," Widener University School of Law (October 2008), online:

$<$ http://works.bepress.com/cgi/viewcontent.cgi?article=1000\&context=sydney_howe_barksdale $>$; Scott L Cummings, "The Politics of Pro Bono" (2004) 52:1 UCLA L Rev 1.

76 Faisal Bhabha, "Institutionalizing Access-to-Justice: Judicial, Legislative and Grassroots Dimensions" (2007) 33 Queen's LJ 139.

77 Ibid at para 27. 
a maximum annual gross income of about $\$ 12,000$ for a single person, ${ }^{78}$ but, according to Statistics Canada, the average gross income in Ontario was approximately $\$ 32,000$ in $2014 .{ }^{79}$ The more significant problem for access to justice occurs where the majority of the public still does not earn enough to hire a lawyer but earns more than the fixed legal aid cut-off. A 2016 Superior Court decision in $R v$ Moodie ${ }^{80}$ in Toronto helps illustrate some of the contemporary challenges with legal aid. ${ }^{81}$ The criminal proceedings against the accused, who was charged with multiple drug offences on a Rowbotham application. ${ }^{82}$ Justice Ian Nordheimer stated: "[6] It should be obvious to any outside observer that the income thresholds being used by Legal Aid Ontario do not bear any reasonable relationship to what constitutes poverty in this country." The accused was denied legal aid because his annual income was more than $\$ 12,000$, but his lawyer's fees would have amounted to almost 70 percent of his earned annual income. ${ }^{83}$ This case is just one example of the many who would benefit from access to a low bono program offered through a legal incubator instead of attempting to rely on government legal aid as a solution. ${ }^{84}$ Whereas most access to justice discourse in Ontario focuses on increasing pro bono, using class actions and contingency fees, ${ }^{85}$ or supplementing access to lawyers through self-help or delegation to other professionals, ${ }^{86}$ the incubator model seeks to restructure how practitioners are organized to change the manner in which they deliver services on the supply side.

Access to justice can also include the advancement of important public policy and constitutional law cases. At the federal level, the former Court Challenges Program [CCP] of Canada offered a collective approach to challenging the institutional deficiencies of access to justice, where direct funding was available to cases involving language and equality rights. ${ }^{87}$ The CCP supported equality issues such as same-sex marriage, violence against women and sex discrimination, and the impact of national security legislation on racialized communities. ${ }^{88}$ In 2005, the constitutionality of national security certificates was challenged at the Supreme Court of Canada with the assistance of funding from the CCP, and it marked

78 Legal Aid Ontario, “Am I Eligible for Legal Aid Certificate?” (2016), online: <www.legalaid.on.ca/en/getting/eligibility.asp>.

79 Statistics Canada, "Individuals by Total Income Level, by Province and Territory" (2016), online: <www.statcan.gc.ca/tables-tableaux/sum-som/101/cst01/famil105a-eng.htm>.

802016 ONSC 3469. See also Jacques Gallant, "Toronto Judge Halts Changes against a Man until Government Pays for Lawyer," Toronto Star (3 June 2016), online: <www.thestar.com/news/gta/2016/06/03/threshold-to-qualify-for-legalaid-too-low-toronto-judge-rules.html>.

81 For some of the adverse impacts of legal aid in the family law context, see Omar Ha-Redeye, "Sometimes Legal Aid is the Problem, Not the Solution," Slaw (19 March 2017), online: <www.slaw.ca/2017/03/19/sometimes-legal-aid-is-theproblem-not-the-solution/>.

82 These motions come from the case of $R v$ Rowbotham, 1988 CanLII 147, and are being used with increasing frequency in Toronto. See also Omar Ha-Redeye, "Increasing Funding for Legal Aid Is Not Enough,” Slaw (5 June 2016), online: $<$ www.slaw.ca/2016/06/05/increasing-funding-for-legal-aid-is-not-enough/>.

83 Gallant, supra note 80.

84 For more information on how practice, clinics, and poverty law can assist the impoverished, see generally Stephen Wexler, "Practicing Law for Poor People" (1970) 79:6 Yale LJ 1049; Stephen Loffredo, "Poverty Law and Community Activism: Notes from the Law School Clinic" (2001) 150 U Pa L Rev 3; H Grant Timms, "Social Welfare Programs under Pressure: The Role of Legal Clinics as Facilitators of Poverty Law Reform Activities" (1993) 9 JL \& Soc Pol'y 116.

85 Kent Roach \& Lorne Sossin, "Access to Justice and Beyond" (2010) 60:2 UTLJ 378.

86 Paul A Vayda \& Stephen B Ginsberg, "Legal Services Plans: Crucial-Time Access to lawyers and the Case for PublicPrivate Partnership" in MJ Trebilcock et al, eds, Middle Income Access to Justice (Toronto: University of Toronto Press, 2012) 246 at $250-253$.

87 Bhabha, supra note 76 at para 34.

$88 \quad$ Ibid at para 37. 
the first time that Muslim organizations addressed the Court on behalf of their communities. ${ }^{89}$ However, the restriction of CCP funding to government actions under federal jurisdiction meant that legal challenges to most social programs were excluded because they fell under provincial jurisdiction. The additional restriction to language and equality rights meant that litigants could not use legal arguments based on other rights in the Canadian Charter of Rights and Freedoms. ${ }^{90}$ In 2006, the CCP was terminated as part of a series of social spending cuts. ${ }^{91}$

Perception of access to justice is fundamental in building trust and confidence in the justice system, ${ }^{92}$ since excluding low-income people from the justice system "can exacerbate and entrench their already marginal position in the political, social and economic structures of society." "Canadian law schools and legal practitioners would do well to emulate their American counterparts and consider creating neighbourhood-based incubators that encourage low bono legal services. On a local level, establishing legal incubators in neighbourhoods can build community supports and address the everyday legal issues of residents. Incubators have the potential for providing services to those who remain marginalized and otherwise underserved, while providing young practitioners with the opportunity for skill building and practice development in areas such as family law, immigration and refugee law, and residential tenancy law. ${ }^{94}$ Under a low bono fee structure, the cost to operate an incubator is modest compared to a traditional practice and pales in comparison to the benefits in long-term access to justice and endless education opportunities in fostering competent, qualified legal professionals. ${ }^{95}$

\section{HOW THE INCUBATOR WAS CREATED}

\section{A. Inception of Fleet Street Law}

Decision making by consensus is complicated at the best of times and tortuous at the worst. All of the founders within Fleet Street Law wanted to maintain their own independent practice, while still looking for ways to assist and collaborate with one another. In part, this was motivated by an interest in minimizing liability. It was also beneficial to allow for micro-experiments in practice management and innovative approaches without the need for consultation and approval, one of the biggest drawbacks of traditional practice within a larger firm setting. The egalitarian and non-hierarchical nature of the group was one of the biggest attractions to participation, but it could at times also be one of its greatest downfalls. This limitation became apparent at the outset with the mere selection of the name. Suggestions were elicited through a modified Delphi technique, obtaining an initial round of names, which were then collaborated and distributed among the group for secondary feedback. ${ }^{96}$ The feedback by other participants was maintained anonymously, so others could get a sense of where the group was going as a whole. Between five individuals, over ninety different names were proposed. Some of them conflicted with a preliminary NUANS search, and none of them received unanimous support.

\footnotetext{
Ibid at 72 .

90 Ibid at 40. Canadian Charter of Rights and Freedoms, Part 1 of the Constitution Act, 1982, being Schedule B to the Canada Act 1982 (UK), 1982, c 11.

91 Bhabha, supra note 76 at 38.

92 Waites \& Rooney, supra note 50 at 519.

93 Bhabha, supra note 76 at 54.

94 Ibid at 509.

95 Herrera, "Encouraging the Development," supra note 68 at 10.

96 Mark J Clayton, "Delphi: A Technique to Harness Expert Opinion for Critical Decision-Making Tasks in Education" (1997) 17:4 Educational Psychology 373.
} 
Ultimately, the name - Fleet Street Law - was selected because it was the name that the group disagreed with the least. Appeal for this name stemmed from a myriad of different interests, reflective of the personalities and backgrounds of the different lawyers. The original designation stemmed from Fleet Street in London, England, where the Royal Courts of Justice and a number of barrister chambers were historically concentrated and continue to be located to this day. ${ }^{97}$ Fleet Street was also known for housing the Serjeant-at-Law, an order of senior members of the English bar that preceded the King's/Queen's Counsel. The term Fleet Street in legal history, therefore, has some significance towards exemplary practice in the law, ideals, and goals to which the members of the group aspired. ${ }^{98}$

The group took particular note of a 2011 summary judgment motion, Tiago v Meisels, ${ }^{99}$ where four lawyers were sharing office space and were jointly sued, despite maintaining separate legal practices. This risk of being found liable for negligence was an extremely important consideration from the outset. Some of the steps taken to mitigate this issue included the incorporation of the name Fleet Street Law under a distinct legal entity, clearly indicating on all marketing materials and documents that there were separate legal entities involved. At the initial meeting with clients, they were clearly informed in writing with whom they were securing legal services. Written consent was obtained with the retainer agreement, and they received waivers of confidentiality where necessary.

\section{B. Changes and Transition to an Incubator}

The impetus behind shifting from a law chambers to a legal incubator arose largely out of early interactions with the regulator. The LSUC routinely conducts audits of sole practitioners in their first few years of practice, and Fleet Street Law participants were no exception. The Spot Audit Program is authorized under section 49.2 of the Law Society Act and is intended to provide on-site remedial guidance for financial filing, record keeping, and compliance with the Rules of Professional Conduct. ${ }^{100}$ The challenge that Fleet Street Law participants encountered was that auditors expressed conceptual difficulty with a chambers or association that was not located in the same place and were unsure how this fit into the regulations. ${ }^{101}$ There were some inquiries whether there should be global conflict checks, whether confidential material was shared, or whether Fleet Street Law itself was a legal services provider. To help respond to this regulatory scrutiny, and better describe the nature of our operations, the organization was

97 Rao V Venkata, “What Is Fleet Street in London Known For?” Times of India (2 August 2009), online:

$<$ http://timesofindia.indiatimes.com/home/sunday-times/What-is-Fleet-Street-in-London-known-

for/articleshow/4846873.cms?>

98 The accumulation of barristers around Fleet Street also led to another related phenomenon. Starting in the 1500s, large numbers of publishers and printers started opening up on Fleet Street, presumably to service the legal industry. By the 1700 s, the first newspaper in London opened there, followed by several other newspapers. The term "Fleet Street" became synonymous with the media by the twentieth century in England, in the same way that the fourth branch of government or the "Fourth Estate" is used to describe the media in North America. Some of the founding members had a strong interest in public policy and media participation, and the name Fleet Street appealed for that reason. 2011 ONSC 5914.

100 RSO 1990, c L.8. Law Society of Upper Canada, Rules of Professional Conduct (22 June 2000).

101 Although Fleet Street Law was never itself a legal services provider, the definition and delineation of a firm has been discussed in the context of providing poverty law services. An expansive definition can be advantageous because more people can be consulted without violating clients' rights, but fewer problems emerge for conflicts of interest if a firm is defined as small as possible. See Nina W Tarr, "Ethics, Internal Law School Clinics, and Training the Next Generation of Poverty Lawyers" (2008) 35 Wm Mitchell L Rev 1011 at 1016, online: <http://open.mitchellhamline.edu/wm1r/vol35/iss3/9/>. The discussion in this article is limited to the specific rules of confidentiality in Ontario, how they have been interpreted in light of conflicts by courts in recent years, and the manner in which these competing interests were balanced by avoiding a firm definition and still drawing on collaborative resources. 
rebranded in late 2013 as a "legal incubator."102 The intent of this new focus was to provide time-limited support and resources to new practitioners to assist them in the early stages of the business cycle, with the goal of having them establish entirely independent practices or pursue other career alternatives. The novelty of this type of structure had never been previously addressed in this jurisdiction, so the participants found some guidance from the decisions addressing privilege around associations.

The complicated nature of solicitor-client privilege in associations was addressed by Master Benjamin Glustein in a motion from Jajj $v 100337$ Canada Limited, which was released immediately prior to the rebranding. ${ }^{103}$ The motion was to remove a lawyer of record due to consultation between lawyers who work together in association. Although Master Glustein was able to refer to ample case law on how to deal with these situations in the traditional law firm context, he cited the two-part test by the Supreme Court of Canada in MacDonald Estate v Martin:

1. If the client satisfies the court that there existed a previous relationship with the lawyer which is sufficiently related to the retainer at issue, the court should infer confidential information was imparted unless the lawyer satisfies the court that no information was imparted which could be relevant. The Supreme Court held that this would be a difficult burden to discharge, since the lawyer would have to do so without revealing the specifics of the privileged communication; and

2. If a lawyer had relevant confidential information from the client, that lawyer could not act against the client in that matter. ${ }^{104}$

However, these principles do not apply in the same way for associations. He stated:

[9] Lawyers with separate practices who work in association should not be presumed to be discussing the file with other separate practitioners who share premises or share some support staff. Such a presumption would be contrary to the lawyer's professional and ethical obligations. Consequently, a reasonably informed client would not expect his or her lawyer to share confidential information with any other lawyer in the association, unlike the situation in MacDonald Estate in which partners and associates work in a law firm and the client's reasonable expectation is that all resources of the firm are available to assist the client. $^{105}$

He concluded that these determinations should be made on a case-by-case basis and alluded to the desirability of permitting lawyers to operate in association while maintaining separate practices, and he went further and stated that even making the disclosure to other lawyers in the association that they were consulted or retained could violate the independent practitioner's obligations of confidentiality, even if it was for the purpose of a conflict check. ${ }^{106}$ The application of these principles in Jajj meant that members of the incubator could rely on section 3.3 of the Rules of Professional Conduct to dispute the suggestion

\footnotetext{
102 Omar Ha-Redeye, “Legal Incubators for Innovation and Access to Justice," Slaw (2 December 2013), online: $<$ www.slaw.ca/2013/12/22/legal-incubators-for-innovation-and-access-to-justice>.

1032013 ONSC 5743.

104 [1990] 3 SCR 1235 [Martin].

105 Ibid (emphasis added).

${ }^{106}$ Ibid at paras 10, 11.
} 
that global conflict checks were needed. ${ }^{107}$ Although these consultations did occur, it was on a case-bycase basis and with the express consent of the client. To complicate it further, most of the lawyers were not co-located and did not have the same difficulties around conflicts or confidentiality as in Jajj and related cases. To better describe the direction Fleet Street Law had taken, the terms "practicing in association" or "chambers" fell into disuse in preference for "legal incubator," which was the first of its kind in Canada.

Regulatory burdens can often inhibit or promote innovative business models. ${ }^{108}$ The LSUC, which focuses on the public interest and is far more accustomed to traditional type practice models, is an important stakeholder worth considering when considering an incubator model for meeting public needs. Foremost among the LSUC's concerns in this context is preserving client confidentiality. ${ }^{109} \mathrm{~A}$ recent Ontario Superior Court of Justice decision in 1623242 Ontario Inc. v Great Lakes Copper Inc. provides some guidance on how confidentiality can be preserved and assurances that practitioners can still mentor each other without violating the Rules of Professional Conduct. ${ }^{110}$ The decision deals with a motion for a determination as to whether a lawyer is precluded from representing opposing parties in litigation if they have previously provided legal information that benefits another lawyer's client as a result of inquiries made to enhance competence in practice. Although the parties disputed whether any confidential information was discussed during the call, Justice David Price commented on the importance of consultations between junior and senior practitioners:

[58] While a client's relationship with a senior lawyer who provides information to the client's own lawyer is arguably more proximate than the client's relationship with an opposing lawyer who provides such information, I find that neither type of consultation, by its nature, gives rise to a duty of care. It is the client's own lawyer who owes the duty to his client, plain and simple. It is that lawyer who must weigh what he is told by another lawyer, whether it be an opposing lawyer or a senior member of the Bar whom he consults. It would undermine the relationship between a solicitor and client and substantially erode the accountability of a solicitor to his own client to hold otherwise.

...

[60] To hold that a lawyer whom a junior counsel consults, and who provides general information without receiving confidential information about the client, is thereby precluded from representing any party who is adverse in interest to the junior lawyer's client would have an equally unwarranted and similarly chilling effect.

107 The extent to which lawyers in Ontario consult their professional codes of conduct when facing ethical decisions is further explored in Margaret Ann Wilkinson et al, "Do Codes of Ethics Actually Shape Legal Practice?” (2000) 45 McGill LJ 645, online: <http://ir.lib.uwo.ca/cgi/viewcontent.cgi?article=1057\&context=lawpub>.

Knut Blind, "The Impact of Regulation on Innovation" in Jakob Edler et al, eds, Handbook of Innovation Policy Impact (Northampton, MA: Edward Elgar Publishing, 2016) 450. See more generally, in Canada, External Advisory Committee on Smart Regulation, "Smart Regulation: A Regulatory Strategy for Canada" (September 2004) at 10, 17, online: $<$ http://publications.gc.ca/collections/Collection/CP22-78-2004E.pdf $>$.

109 Lawyer exceptionalism, as related to other regulated markets, is often most pronounced when examining lawyer confidentiality. Richard Devlin, "Breach of Contract?: The New Economy, Access to Justice and the Ethical Responsibilities of the Legal Profession" (2002) 25 Dalhousie LJ 335 at 362. In some instances, this can create a structural barrier to justice directly related to a growing disconnect and dissatisfaction among lawyers for their relevance to society as a whole. David M Tanovich, "Law's Ambition and the Reconstruction of Role Morality in Canada" (2005) 28 Dalhousie LJ 267 at 268-269, online: <https://papers.ssrn.com/sol3/papers.cfm?abstract_id=764606>.

1102014 ONSC 782. 
[61] ... The myriad of places, times, and circumstances in which such requests are made, including taxi cabs, restaurants, and parking lots, makes it impossible, in many cases, for the recipient of the request to run a conflicts check before responding. ${ }^{111}$

To avoid conflicts of interest between participants in an incubator, lawyers should refrain from acting on opposite sides of matters in litigation wherever possible. In large urban areas, this is typically not a problem and often is not as significant an issue in typical access-to-justice files where there is a public individual client being serviced against a larger institutional party. Avoiding conflicts should not require onerous and time-consuming global conflict checks, and doing so should not create an unwieldly administrative obstacle to practice. ${ }^{112}$ Instead, lawyers in an incubator should consider the context in which any information or request for advice is provided. Specifically, they should examine whether there is any confidential information that could be attributable to a solicitor-client relationship and whether there is a risk that this information will be used to prejudice a client. ${ }^{113}$ Facilitating senior and specialized practitioners in providing advice to junior colleagues or general practitioners is in the public interest and is one of the most significant resources that can be used in innovative models to strengthen practices. ${ }^{114}$

\section{RESOURCES AND INNOVATIVE MODELS}

\section{A. Resources Used to Strengthen Practices}

The supports offered as part of the incubator varied over time, prompted and adapted by the changing needs of the participants. These supports helped create the financial environment where practitioners could sustain a financially viable practice and thereby assist those who would not normally access legal services. The very first support instituted was a web presence, through the creation of a website. It featured pages for each of the lawyers and practice areas, with links to the individual lawyer's website. This latter component was essential in illustrating a separation between the incubator and the individual practice, either as a "barrister \& solicitor" or as a professional corporation. For the reasons described in Jajj, avoiding confusion among the public or potential clients was a significant priority, and it was important to illustrate this on all public-aimed materials. Over time, some of the participants added their own links for Fleet Street Law to their website. Through these interlinkages, the search engine optimization [SEO] of Fleet Street Law was enhanced, and web users could flip between the respective websites. ${ }^{115}$ SEO was important given the public nature and access-to-justice orientation of many of the client services, as the primary tools used by many of these clients were the Internet search results.

Metrics about visitors were carefully collected and analyzed and, when appropriate, shared with incubator participants to help enhance business strategies. For example, throughout the entire project, there has been a strong interest and demand in family law. When there was an active practitioner in this

\section{Ibid.}

112 The use of conflict checks specifically for the purposes of acting as co-counsel on files is further discussed below.

113 Martin, supra note 104 at 1259-1260.

114 Julius Melnitzer, "Ruling a Relief to Lawyers Asked for Friendly Advice," Law Times (10 March 2014), online: <www.lawtimesnews.com/201403103830/headline-news/ruling-a-relief-to-lawyers-asked-for-friendly-advice>.

115 Links from reputable sites are often considered to be one of the best ways to improve standing under the Google algorithm. Krystian Wlodarczyk, "Google Algorithms and What They Mean to Your Website," Positionly (18 October 2013), online: <http://positionly.com/blog/seo/google-algorithms-and-what-they-mean-to-your-website>. Despite numerous changes to the Google algorithm, inbound links are still considered to be an important and significant factor to search engine results. Jayson DeMers, "Why Links Are Still the Core Authority Signal in Google's Algorithm," Search Engine Land (11 August 2016), online: <http://searchengineland.com/links-still-core-authority-signal-googlesalgorithm-255452>. 
area listed on the website, that person would receive more web traffic and more inquiries for their services. To further illustrate that the incubator was not a legal services provider, a page about legal incubators was prominently displayed. Some of the most important features of the website were the maps and contact information for the various practitioners. Since the network of lawyers is dispersed across Toronto, many web viewers had an interest in identifying locations where they could find a lawyer closer to their vicinity. Over time, there were a number of offices listed here, which were periodically opened or closed and not maintained directly by the incubator at all. This allowed these practitioners to increase their referral base directly to their office and channel interest from prospective clients in their direction. Strategic partnerships and cooperation with established practitioners, publishers, and vendors always played a crucial role with the legal incubator.

The first of these partnerships was established with LexisNexis, soon after the inception of the project in 2011. LexisNexis offered every single participant in the project a free copy of PCLaw Practice Suite (which has since been rebranded), so the group could beta test and experiment with the new platform before it went to market. ${ }^{116}$ Practice management software was essential for many participants, especially because of the concerns around audits. The biggest advantage of this software was that it was developed specifically for legal practice in Ontario. Lawyers engaging in multiple high-level transactions as part of their practice, such as real estate, found the software particularly useful. Others were bogged down in the technicalities of the system, found it too redundant or complicated, or were turned off by its limited remote capabilities. This final limitation proved especially difficult for lawyers who moved to a virtual, remote, or mobile practice, which eventually happened for most of the participants.

Over time, a stronger partnership was created with Clio, the largest cloud-based practice management system in the world. As a Canadian company operating primarily in the American market, they were interested in creating relationships with influential Canadian lawyers. The cloud capabilities of Clio, including a billing application that was usable on a smartphone, proved far more popular among the participants, likely reflecting the mobile and less permanent nature of their practices. The only significant downside with the use of Clio came with the creation of LSUC-compliant reports for auditing purposes. Few legal accountants were familiar with Clio and they had difficulty extracting the information and formatting it in a familiar way for the LSUC auditors. In part, this had to do with preconceived notions of compliance on behalf of the auditors themselves. The status of PCLaw as the software of choice in Ontario meant that this was what the auditors were accustomed to seeing. Although other formats may have been compliant with bylaws, this was not always readily apparent on first instance during an audit. For some accountants, the formatting and export of data from Clio did not always work well, particularly if they were extracting the data to input into another non-legal accounting system like QuickBooks. With the further development of these alternative platforms, and greater familiarity with these alternatives among legal accountants, such challenges will hopefully be diminished in the future. One final strategic partnership worth mentioning was with DivorceMate software, a necessity for family law practitioners in Ontario. DivorceMate maintained a strong interest in supporting new and independent family law practitioners since there was an acute need for younger lawyers to practise in this area.

Other methods of helping the independent practices grow included listings and participation in legal marketing or directory sites. Some of these sites provided listings at a discount or for free in the interest of assisting junior practitioners who were getting their practices off the ground. Some of the low-income members of the public looking for legal services utilized these sites extensively, and they were one way

116 Omar Ha-Redeye, “LexisNexis PCLaw Practice Suite," Slaw (13 November 2011), online:

$<$ www.slaw.ca/2011/11/13/lexisnexis-pclaw-practice-suite/>. 
of funnelling prospective clients towards young practitioners. The difficulty with these prospective clients was their inability to pay a retainer deposit or to pay for bills once services were rendered. With the exception of contingency fee files, this approach was usually not a fruitful way to grow a practice. Alternatively, numerous files came to the incubator participants through referrals through the bar. Close relationships with established practitioners were fostered primarily through legal organizations such as the OBA or the Advocates Society. Specialty legal organizations such as the WLAO, the CABL, the FACL, and others were also instrumental. The expense of joining these organizations, which could be quite high for junior practitioners, was a major obstacle in the early years of practice.

One of the most expensive and significant services provided to incubator participants was office space in a prime downtown location, located close to both the subway and the courts. This downtown office space consisted of several permanent offices, a boardroom, as well as up to a dozen cubicles for virtual practitioners and students. The majority of the furniture was donated by other lawyers closing or moving their offices, and the remainder purchased secondhand from websites like Kijiji or Craigslist. The office space was maintained from 2012 to 2015, with several lawyers renting permanent offices and others paying for a virtual office. The virtual tenants obtained access to the boardroom, subject to booking, as well as a mailing address, fax number, and telephone extension. A voice-over-Internet-protocol phone system was used, with the advantage that an extension could automatically be forwarded to a home phone or cell phone, facilitating virtual or mobile practice seamlessly and without disruption to clients.

The biggest limitation with the office space was that all of the incubator participants did not make use of it and therefore resisted contributing financially to the overhead. These other practitioners had already established their own offices or practice arrangements and did not have a need for the central office space. Rather than requiring their participation, these alternate arrangements were integrated, which included ancillary agreements to use these other locations as needed. The overall trend over this period, however, was an increased interest in maintaining a strictly virtual practice. Developments in technology allowed this to be a more feasible manner of practice, and the cost-effectiveness of virtual arrangements assisted practitioners in their initial years of practice. Over time, the virtual option became the preference for nearly all of the participants, resulting in a decision to close the physical office space in 2015. This ultimately proved to be a better decision, as the incubator was able to reduce its membership fees by approximately 90 percent. With the single largest overhead expense removed, the remaining expenses were covered by a nominal fee. The expense of legal operation is important to highlight as it remains the main reason why practitioners cannot or will not assist underserviced populations. Reducing operating expenses allowed more pro bono and low bono services to be offered.

Aside from rent, the most significant operating expense for any law practice is salaries. Some of the participants maintained law clerks or legal assistants, usually on a contract or part-time basis. These arrangements allowed for scalability in practice instead of a flat rate for staffing even when the demand did not justify the expense. Assistance on files also came from other practitioners, using a "swarm method," described in the next section. A variety of students from a number of different programs also completed internships with the incubator. The students ranged from legal assistants, law clerks, paralegals, public relations, law students, and articling/LPP candidates, and they were all involved in a wide number of tasks and aspects of practice. Most of these students were not paid for their work, absent some prearranged stipends, as traditional wage models were not financially feasible for practitioners who had just established their business.

Given the strong public interest and access-to-justice orientation of the incubator, concerns over the exploitation of student labour were a priority for incubator participants. The Ministry of Labour increased 
its scrutiny of unpaid internships during this time, ${ }^{117}$ including a number of blitzes focusing on noncompliance with minimum wage, ${ }^{118}$ but the incubator was able to avoid these complications. The Employment Standards Act contains an exception for minimum wage under section 3(5)2 for individuals completing a program in a college or university. ${ }^{119}$ Almost all of the internships with Fleet Street Law fell under this exception, as the students received credits for their programs. The very small number who were not completing a formal education program fell under the exception to the definition of "employee" under section 1(2) of the Act, describing internships with a primary purpose of providing training that creates little benefit to the employer. ${ }^{120}$

With over fifty students going through the incubator in five years, practitioners were able to obtain some assistance with file management, client development, and legal research. The paralegal and articling/LPP students were able to appear in court for some minor matters. Public relations students assisted with promotional materials, website design, document review, and editing. These students, who could be pooled or shared between practitioners, were used in conjunction with assistance from other lawyers. Cost-effective assistance on files not only helped ameliorate some of the biggest issues faced by sole practitioners but also created cost savings that could be passed onto the clients in providing low bono services. A lower fee model is ultimately what best facilitates accessible legal services, as clients cannot obtain comparable assistance through lawyers operating in a traditional practice model.

Despite such cost savings, many of the new practitioners still required some capital investment. Where this was not available in the form of bank loans, other resources were investigated. The final material support that Fleet Street Law has tried to introduce is the use of microcredit loans. ${ }^{121}$ The incubator developed a strategic partnership with a Canadian registered charity that helped entrepreneurs with viable business plans. The loans were disbursed through established banks and ranged from $\$ 5,000$ to $\$ 10,000$. These loans were earmarked to assist socially minded individuals and organizations, and they were also available to those with poor or no credit history. The strong commitment of the incubator and its participants to access to justice meant that these practitioners could be eligible for such loans.

117 Ontario Ministry of Labour, “Are Unpaid Internships Legal?” (2011), online: <www.labour.gov.on.ca/english/es/pubs/internships.php>.

118 Ontario Ministry of Labour, "Internships Focus of Autumn Blitz" (2015), online: <www.labour.gov.on.ca/english/es/inspections/internship20151014.php>.

119 SO 2000, c 41. A similar exception exists under s 3(5)6 for "[a]n individual who performs work in a simulated job or working environment if the primary purpose in placing the individual in the job or environment is his or her rehabilitation."

120 See also Ministry of Labour, “Are Unpaid Internships Legal in Ontario?” (June 2011), online: $<$ www.labour.gov.on.ca/english/es/pubs/internships.php $>$. This exception was not as beneficial to practitioners since the students were most heavily involved with pro bono or low bono projects.

121 Microcredit loans and microfinancing have been demonstrated as a highly effective approach to fostering the growth of small business enterprises. See Deborah Burand \& David W Koch, "Microfranchising: A Business Approach to Fighting Poverty" (2010) 30:1 Franchise LJ 24, online: <http://plavekoch.com/wp-content/uploads/2014/11/Microfranchising_-ABusiness-Approach-to-Fighting-Poverty-FLJ-2010.pdf >; Milford Bateman, "Microfinance as a Development and Poverty Reduction Policy: Is It Everything It's cracked up to be?" Overseas Development Institute Background Note (2011), online: <www.odi.org.uk/resources/docs/6291.pdf>; Muhammad Yunus, Banker to the Poor: Micro-Lending and the Battle against World Poverty (New York: Public Affairs, 2003); Muhammad Yunus, Bertrand Moingeon \& Laurence Lehmann-Ortega, "Building Social Business Models: Lessons from the Grameen Experience” (2010) 43 Long Range Planning 308, online: <www.hec.edu/var/fre/storage/original/application/271185ec82c9984a0826028c$3 \mathrm{~d} 3$ bae45.pdf $>$. 


\section{B. Innovative Structures, Unbundling, and Swarming}

The flexible and constantly changing nature of the incubator allowed for endless experimentation and innovation. Some of the practices worked better for specific personalities or for specific areas of law. For example, flat fee structures worked better in civil litigation, with fees set at each stage of the process. The incubator participants also experimented with limited scope retainers, and some created a niche in providing independent legal advice on certain matters. Unbundled legal services, which are a relatively new development in Ontario, offer a way for clients to obtain some limited legal assistance on a matter without the expense of a full retainer. The unbundled services provided can normally be grouped into three distinct types: providing representation in court; preparing documents and forms; and engaging in coaching or training of parties. Streamlining the services in this way allows clients to obtain the legal assistance for which they have the greatest need. For the practitioner, there is an opportunity to gain additional experience in a limited fashion without the complete responsibility of a full retainer.

However, unbundled services are not without risk. LawPRO, the insurer of lawyers practising in Ontario, considers the top two reasons for claims against lawyers - communication issues and inadequate investigation or discovery of facts - as greater risks with unbundled services than with a traditional retainer given the limited involvement of the client with the practitioner. ${ }^{122}$ Unbundled services were officially adopted in Ontario in 2011 with changes to the Rules of Professional Conduct ${ }^{123}$ The new Rule 3.2-1A.1 requires such arrangements to be made in writing and provided to the client. Explicitly outlining the limited nature of the representation in the retainer agreement has proven to be the best approach. The requirement to have the arrangement in writing does not apply to certain duty counsel or clinic services that would fall under the Legal Aid Services Act. ${ }^{124}$ If a legal incubator was created as an extension of an existing clinic, these rules would apply in a different manner. LawPRO has recognized that these arrangements are "one solution to the complex issue of access to justice," and it has developed a number of resources to assist with the provision of unbundled services. ${ }^{125}$

An unanticipated advantage of collaboration under the umbrella of an incubator was the growth and development of solicitor-type practices. Real estate law, which can be very popular among sole practitioners, but is also wrought with risk of fraud and malpractice claims, ${ }^{126}$ was an area where high volume could be coupled with greater mentorship and supports. Small business law, including simple incorporations, general contracts and agreements, employment issues, and basic intellectual property

122 LawPRO, “Unbundled Services: Pitfalls to Avoid” (2012) 11:1 LawPRO Magazine, online: <http://practicepro.ca/lawpromag/Unbundled_Legal_Services.pdf $>$.

123 The Law Society of Upper Canada, "Law Society provides guidance on "unbundling" of legal services," (2011), online: $<$ http://www.lsuc.on.ca/WorkArea/DownloadAsset.aspx?id=2147485669>.

124 SO 1998, c 26.

125 LawPRO, “Limited Scope Representation Resources" (2016), online: <www.practicepro.ca/practice/limitedscope.asp>. The primary source for all claims against lawyers in Ontario is communication problems. Tim Lemieux,

"Communication Breakdown" (2011) 10:2 LawPRO Magazine, online:

$<$ www.practicepro.ca/lawpromag/Communications-claims-causes.pdf $>$. For further reading on client communications, see Jacquelyn Lynn, "Dealing with Difficult Clients" (1996) 11.6 Commercial Law Bulletin 10; Carole Curtis, "Dealing with the Difficult Client," practicePRO (October 2013), online: <www.practicepro.ca/practice/pdf/dealingdifficultclientcarolecurtis.pdf $>$; Loretta J Bradley et al, "E-mail Communication with Clients: Some Ethical Concerns," American Mental Health Counselors Association (2011), online: $<$ http://counselingoutfitters.com/vistas/vistas11/Article_62.pdf>; Clark D Cunningham \& W Lee Burge, "What Do Clients Want from Their Lawyers?" (28 August 2012), online: < http://law.gsu.edu/ccunningham/PR/WhatClientsWant-28Aug12.pdf>.

126 Kathleen Waters, "Six Things LAWPRO Hates to See in a Real Estate Transaction," practicePRO (23 January 2017), online: <http://avoidaclaim.com/2017/lawpro-tales-of-horror-six-things-lawpro-hates-to-see-in-a-real-estatetransaction $/>$. 
protections, ${ }^{127}$ could be provided in a more efficient and cost-effective manner, also helping support entrepreneurs and small businesses in minority communities. ${ }^{128}$ Although many law school clinics have not historically focused on imparting business law, the concept of a business law clinic is growing in popularity, especially in its ability to help law students understand business needs. ${ }^{129}$

Despite this growth, most transactional clinics still do not have any formalized teaching materials and lack any pedagogical focus, while others conclude that law schools simply cannot teach the practical skills required for training business lawyers. ${ }^{130}$ Incubator participants were able to obtain, share, and modify precedents in the same manner as practitioners in a larger firm context. In addition, their exposure to small businesses, which often deal with the same cost centres and similar operational issues as a new law practice, imparts transferable business lessons. ${ }^{131}$ These lessons then either helped inform their own business practices or helped with decisions about future career directions. ${ }^{132}$ Transactional legal assistance offered to not-for-profit enterprises, advocacy organizations, and non-governmental organizations has the additional effect of providing strategic and cost-effective support to institutions that will further advance equity issues more broadly in society. ${ }^{133}$ Where small businesses were owned or situated in economically disadvantaged neighbourhoods and communities, the longitudinal effects of this type of transactional work includes the creation of new jobs. ${ }^{134}$

On larger files, the incubator developed a process whereby other resources and practitioners could be drawn into tasks. This became known as a "swarm model," where other sole practitioners and affiliated resources could develop ad hoc teams for document review, interlocutory stages within litigation, preparation for trial, or more complex business transactions. Clients were largely supportive of this

127 For the use of interdisciplinary transactional clinics to teach intellectual property for entrepreneurs, see Sean M O'Connor, "Teaching IP from an Entrepreneurial Counseling and Transactional Perspective" (2008) 52 St Louis U LJ 877 at $886-888$

128 Transactional law clinics with law students have also demonstrated the ability to handle and process complex projects involving multiple parties and issues over a longer duration of time, but the disruption of having these projects transfer between students across semesters can pose certain challenges. Laurie Hauber, "Complex Projects in a Transactional Law Clinic" (2009) 18 Journal of Affordable Housing \& Community Development Law 247 at 254. Handling these same projects in a lawyer incubator would not pose the same problems with student turnover.

129 Eric J Gouvin, "Learning Business Law by Doing it: Real Transactions in Law School Clinics" (2004) 14 Business Law Today 53, online: <http://apps.americanbar.org/buslaw/blt/2004-09-10/gouvin.shtml>; Susan Jones \& Jacqueline Lainez, "Enriching the Law School Curriculum: The Rise of Transactional Legal Clinics in US Law Schools" (2014) 43 Wash U J L \& Pol'y 85, online: <http://openscholarship.wustl.edu/law_journal_law_policy/vol43/iss1/9>.

130 Robert R Statchen, "Clinicians, Practitioners, and Scribes: Drafting Client Work Product in a Small Business Clinic" (2011) 56 NY Law School L Rev 233 at 242, 252, online:

$<$ https://papers.ssrn.com/sol3/papers.cfm?abstract_id=1972447>.

131 The business problems of many of these businesses are as significant as their legal problems. Eric Gouvin et al, "Interdisciplinary Transactional Courses" (2011) 12 Tennessee J Business L 101, online:

$<$ http://trace.tennessee.edu/transactions/vol12/iss3/8/>.

132 This approach has been used by the University of Missouri-Kansas City incubator program described above; see Anthony J Luppino, "Minding More Than Our Own Business: Educating Entrepreneurial Lawyers through Law SchoolBusiness School Collaborations” (2007-2008) 30 W New Eng L Rev 151 at 190-191, online:

$<$ https://papers.ssrn.com/sol3/papers.cfm?abstract_id=1285011>.

133 These types of services are often provided by law school transactional clinics as well for similar purposes. See, eg, Dina Schlossberg, "An Examination of Transactional Law Clinics and Interdisciplinary Education" (2003) 11 Wash U JL \& Pol'y 195, online: <http://openscholarship.wustl.edu/law_journal_law_policy/vol11/iss1/8>.

134 Susan R Jones, "Supporting Urban Entrepreneurs; Law, Policy, and the Role of Lawyers in Small Business Development” (2007) 30 W New Eng L Rev 71 at 71-72, online: <http://digitalcommons.law.wne.edu/cgi/viewcontent.cgi?article=1035\&context=lawreview $>$; Praveen Kosuri, “'Impact' in 3D - Maximizing Impact through Transactional Clinics” (2011) 18 Clinical L Rev 1, online: <http://ssrn.com/abstract=1932256>. 
approach as it provided the expertise and resources of a larger firm, without the same overhead and expense. The model could also be scaled down during slower times in the litigation process, during settlement negotiations, or when the workflow slowed due to delays on the other side. Conflict checks obviously had to occur at the outset of such arrangements, and a number of files did in fact reveal potential conflicts despite the small number of practitioners involved. This swarm model proved useful in allowing new practitioners exposure to files that they otherwise would not have in a small independent practice and the ability to take on tasks or observe procedures for which they did not have training during law school or articling. Often this participation could be obtained at a discount price or even for free since the new practitioner would be eager to develop the experience. The ability to receive assistance from others, especially during trial, provided enormous benefit to the sole practitioner. The bigger challenge here was often in the delegation process and coordinating the different parts. Swarm models and collaboration on files provided opportunities for instructional peer-based learning on substantive law, but it also allowed for discussions and deeper understandings about client confidentiality and the need for conflict checks where necessary. $^{135}$

Incubator participants also developed several technological platforms to improve the delivery of legal services. One of the most notable was MySupportCalculator.ca, the only free and accurate child and spousal support calculator in Canada. Spousal support in Canada is calculated through the Spousal Support Advisory Guidelines, which are non-legislative policies that have essentially become binding through common law. ${ }^{136}$ These complex guidelines cannot be manually calculated and require proprietary software to accurately compute support levels. MySupportCalculator created a simplified version of these calculations and provided it to the public for free. Other examples of software developed independently by incubator participants included MyLegalBriefcase for small claims matters and software for companies incorporating provincially at a lower fee rate.

The most significant role the incubator played in developing technological innovations was in hosting LawTechCamp, an annual conference that brought together the worlds of law and technology for discussions on topical issues. Partnerships with local law schools, social justice organizations, and Ryerson University's LIZ helped with the logistics of hosting the event. The event involved attendees and speakers who were extensively involved in legal technology. Best practices and innovative technological ideas were collected, discussed, and disseminated among incubator participants to help enhance their practices. The incubator therefore played a role in facilitating and advancing technological innovation in Ontario.

\section{LIMITATIONS AND NEXT STEPS}

One of the most significant limitations of Fleet Street Law is that it operates on a cost-recovery basis and makes no profit. The lack of profit incentive was enormously helpful in securing buy-in from partners, who were willing to provide time and resources to our members and participants specifically because these activities were meant to enhance professionalism in the bar. This was especially true given the emphasis and the focus of the incubator in supporting practitioners who may otherwise be marginalized, while also

135 Small discussion groups have also been used in the clinic setting to provide peer feedback on ethical issues such as confidentiality. This approach often works best with the use of a tutor who can identify the appropriate times for ethical dialogue and reflection. Kevin Kerrigan, "How Do You Feel about This Client? A Commentary on the Clinical Model as a Vehicle for Teaching Ethics to Law Students" (2007) 11 Intl J Clinical Legal Educ 7 at 18-19, online:

$<$ www.northumbriajournals.co.uk/index.php/ijcle/article/view/75/78>.

136 Department of Justice, "Spousal Support Advisory Guidelines July 2008” (2008), online: <www.justice.gc.ca/eng/rp-

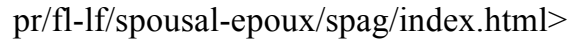


attempting to serve members of the public who may otherwise be overlooked or not properly served by Legal Aid. The greatest success of the incubator was providing strategic and necessary supports to young practitioners at a crucial time in the legal market, when they would otherwise find it impossible to practise or engage in risky practices in service delivery. But there were significant drawbacks, particularly with the lack of stable funding for the support of long-term projects. This was pronounced in the inability to secure any support staff solely dedicated to working on projects. Instead, contributions came from volunteers, interns, students, and the participants themselves, including staff under their direction. The high amount of turnover from incubator participants and students often resulted in non-productive training time.

Despite the best marketing activities or the strongest referral networks, a strong cash flow rarely appeared early in the business cycle due to work in progress and time delayed before billing files. Although many participants did develop sustainable legal practices over the duration of their participation, the first few months were usually characterized by deficits. The strategy that the incubator developed was to recommend that participants maintain a part-time job while setting up their practice. This usually provided stable cash flow during the early stages and allowed practitioners to ease into a full-time practice. One of the best examples of how supplementary income could actually assist with an individual's practice was a participant interested in criminal law, who moonlighted as a bartender in an establishment known for a rough clientele. Over time, she got to know the patrons, who discovered that she was also a lawyer. She soon started receiving cases from her regular patrons at the bar, eventually phasing out the bartending job from her schedule. Other participants maintained a small business in an unrelated field. This turned out to be useful as well, as the transferrable skills from operating a small business were useful for practice management. Some of these businesses grew to the point where participants opted to work in that field rather than continue their legal practice.

Many participants in the incubator took up part-time teaching positions. The burgeoning industry of paralegal education meant that there was a relatively high demand for lawyers to teach in these programs. The close relationships that the incubator participants maintained with local colleges meant that about fifteen of them tried their hand at teaching. The incubator unexpectedly found itself facilitating participants in sharing educational materials and pedagogical techniques. For some participants, this proved to be far more enjoyable than practising law, and they opted to pursue teaching careers instead. The unintended result was that for some incubator participants their involvement meant that they found a way to transition out of law entirely.

Richard Susskind predicts that the legal opportunities of the future will include more of the following types of jobs:

- legal knowledge engineer;

- legal technologist;

- legal hybrid;

- legal process analyst;

- legal project manager;

- online dispute resolution practitioner;

- legal management consultant; and

- legal risk manager. ${ }^{137}$

137 Richard Susskind, Tomorrow's Lawyers: An Introduction to Your Future (Oxford: Oxford University Press, 2012) ch 11. 
Although some of these skills may be taught in a theoretical context in the classroom, incubators can play a role in developing post-graduate training beneficial to the future legal workforce. Luz Herrera notes that post-graduate residency models are being considered and developed at several American law schools, including Arizona State University, CUNY, Georgetown University, Pace University, and Rutgers University. The best practices identified by Herrera in reviewing American law school incubators include faculty support, a dedicated director who is a lawyer, proper financing, and a physical space. ${ }^{138}$

The need for a physical space is useful for the purposes of coordination, even if it is not used for the actual practice itself. The CBA "Futures" report indicates that dedicated time in a lab is key to success for innovation. The report references the HiiL justice innovation lab and indicates that a similar approach can be taken to create a "metaphorical justice lab." 139 This more closely aligns with the model adopted by Fleet Street Law and can be utilized by law schools as well since the shift to virtual practice diminishes the amount of space a legal incubator may need. ${ }^{140}$ Other best practices endorsed by Herrera are a strong alumni network, a focus on innovation, law student counselling, a public service component, and evaluation mechanisms. ${ }^{141}$ She points out that the information about how small and solo practices develop is scant, and she calls for longitudinal studies to identify appropriate supports and to understand the markets they serve, ideally positioning them for innovation. ${ }^{12}$

Financial and time limitations of practitioners imposed challenges in clearly identifying quantifiable best practices in Fleet Street Law. The incubator model proved excellent for allowing a wide variety of ideas and experimentation and providing qualitative data. However, members typically jumped from idea to idea with little time for reflection, and there were few opportunities to document or debrief experiences in detail. Although numerous best practices were identified throughout the project, much of it was in passing, anecdotal, and improperly tracked. This worked well for the purposes of providing peer mentoring and support to one another but was not ideal for the sharing of collective experiences with outside parties. Dedicated roles and resources for the purposes of collecting and analyzing data created in incubators would be a promising way in which to further explore these models for promoting access to justice. $^{143}$

Since the inception of Fleet Street Law roughly coincided with the call to the bar of most of the core founders, the purpose and main objectives of providing peer support internally became less of a priority over time in contrast to other practice-based responsibilities. Between 2015 and 2017, Fleet Street Law scaled down its intake of new incubator participants as well as the offerings it provided. By 2017, Fleet Street Law reduced the number of participants to about half a dozen. The focus of the advisors has also shifted to educational roles, consulting, and business ventures, such as creating legal education programs. This shift in focus might possibly be used to reintegrate developed resources into the legal incubator, but there is also the possibility that other pursuits will make continued participation in the legal incubator

138 Luz E Herrera, "Incubating Community Law Practices: Post-Graduate Models for Lawyer Training and Access to Law" (2016) 2:1 Journal of Experiential Learning 218 [Herrera, "Incubating Community"].

139 CBA, "Futures," supra note 19 at 140.

140 Where an incubator is housed at a law school, it may be useful for law schools to make each incubator project a standalone entity to avoid complex problems of conflicts and confidentiality. This approach has been adopted by clinics in traversing similar challenges. Tarr, supra note 101 at 1016.

141 Herrera, "Incubating Community," supra note 138 at 224.

142 Ibid at 228.

143 Formal quality assurance programs have been implemented for clinics in Ontario, which play a role in monitoring and control. One important consideration in these programs is the separation of confidentiality from any funding decisions. Frederick H Zemans, "The Community Legal Clinic Quality Assurance Program: An Innovative Experience in Quality Assurance in Legal Aid" (2000) 33 UBC L Rev 243 at 262-267, online: <http://digitalcommons.osgoode.yorku.ca/scholarly_works/744/>. 
unfeasible. Regardless of the specific career trajectory undertaken, the high level of customization and the enormous amount of independence afforded to participants typically resulted in high levels of satisfaction. The primary challenge for other similar projects would be to ensure adequate financing while maintaining sufficient autonomy of the project and of its participants, appreciating that the goals of the participants are highly individualized. Given the current focus in the Ontario bar on the lack of early-career opportunities for racialized and minority lawyers in Ontario, the controversy surrounding the LPP program, and the need for greater peer supports in the bar, an incubator model provides some promise in addressing contemporary challenges in legal practice.

\section{CONCLUSION}

Fleet Street Law is a legal incubator operating on the premise that legal services are unaffordable and unattainable to the majority of the public, largely because sustainable practices in these areas of law are elusive for independent practitioners. The methods used to foster and develop new practitioners, particularly those from historically marginalized populations, have resulted in hundreds of individuals in the Toronto area accessing legal services that they otherwise would not be able to afford. This was achieved through the use of cost-minimizing efforts, strong peer mentorship models, and innovative approaches to practice. The project was successful in that it took on a number of young practitioners in small or solo practice, provided supports they would not have received from the bar, and helped advance their careers. One unexpected outcome was the number of lawyers who made a concerted decision to leave the practice of law entirely. This should not be viewed as a failure and should perhaps be reframed as one of the potential goals of a legal incubator.

Participation in legal incubators, and in operating a sole practice, should not be perceived as an option of last resort or as a backup plan if other career alternatives do not pan out. Properly positioned, and drawing on values better expressed in independent practice than in the current legal industry, these opportunities can be viewed as the preferred option. Fostering this perception needs to start prior to graduation, and law schools will have to counter the enormous amount of marketing by large law firms that portray themselves as a superior career choice. The LPP faced similar challenges in its inception and was often described as the alternative for those who could not obtain an articling position. ${ }^{144}$ Since that time, the LPP has been successful in illustrating after its first year of operation how this alternative has assisted numerous licensing candidates in advancing their careers, often opening up opportunities that would not otherwise be available through the traditional articling system. ${ }^{145}$

Connecting incubators to law schools has the additional benefit of allowing licensed practitioners to pass their experiences on to law students. ${ }^{146}$ The combination of an incubator in a law school, providing opportunities for experiential learning to students and practitioners, may actually increase student satisfaction as well. This is particularly important in light of the dissatisfaction expressed by many new law graduates in the education or skills obtained and in the lack of opportunities in the field, sometimes

144 Jennifer Brown, "LPP Year 1," Canadian Lawyer Magazine (24 August 2015), online: <www.canadianlawyermag.com/5711/LPP-year.html>. See also Matt Hopkins, "Don't Bet against LPP Candidates," Canadian Lawyer Magazine (6 October 2014), online: <www.canadianlawyermag.com/5301/Dont-bet-against-LPP-candidates.html>

145 Ibid at 226-227.

146 Law schools in the United States have decided to launch incubators specifically because their students have encouraged them to do so. See Taylor, supra note 57. Institutional sanction for the goals and values have been instrumental in support of clinics in Ontario; Rose Voyvodic \& Mary Medcalf, "Advancing Social Justice through an Interdisciplinary Approach to Clinical Legal Education: The Case of Legal Assistance of Windsor” (2004) 14 Wash U JL \& Pol'y 101 at 102, 104-110, online: <http://openscholarship.wustl.edu/law_journal_law_policy/vol14/iss1/5/>. 
demonstrated through misguided and unsuccessful civil lawsuits against their schools. ${ }^{147}$ Canadian law schools should therefore strongly consider the development of legal incubators. There appears to be some promise in this respect, as several law schools have been in communications with Fleet Street Law as part of a broader investigation as to whether to adopt legal incubators. This is a positive move, and other law schools in Canada should be encouraged to conduct their own independent investigations as to how they may enhance their offerings and make greater contributions towards the profession through practitioneroriented clinical practice.

147 Eg, Elizabeth Olson, "Law Graduate Who Sued Her School Loses at Trial," New York Times (24 March 2016), online: $<$ www.nytimes.com/2016/03/25/business/dealbook/law-graduate-who-sued-her-school-loses-at-trial.html?_r=0 $>$. There are several other lawsuits of this nature in the United States, but to date none of them have enjoyed any success. All are predicated on the notion that the job opportunities provided to them after graduation did not reflect the promises made by the law school. At the same time, the notion that the academy alone can change the world may also be misguided and short-sighted. Lucie E White, "The Transformative Potential of Clinical Legal Education" (1997) 35 Osgoode Hall LJ 603 at 609-610. Law school clinics may provide too narrow a mandate to truly be change agents and may force change agents to actually undermine those who they would assist. The dispersed and autonomous model possible in an incubator may be a better approach to avoid elitist concepts of lawyering through mutually respectful relationships. This is especially important if the model is predicated on the premise that poor people are entitled to as full a spectrum of legal services as the clients of larger corporate law firms. Lucie E White, "Poverty Law and Community Legal Clinics: A View from Parkdale Community Legal Services” (1997) 35 Osgoode Hall LJ 595. 